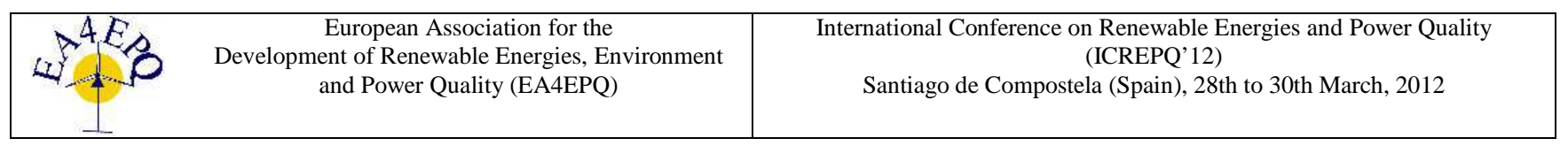

\title{
Merging remote sensing data with in-situ measurements of global solar radiation: the right path to estimate the solar resource in Galicia
}

\author{
A. Pettazzi, S. Salsón \\ MeteoGalicia, Galician Weather Service \\ Consellería de Medio Ambiente, Territorio e Infraestruturas - Xunta de Galicia \\ Rúa Roma, no 6 - 15707 Santiago de Compostela (Spain) \\ Phone/Fax number:+0034 881 999646, e-mail: alberto.pettazzi@meteogalicia.es, $\underline{\text { santiago.salson@meteogalicia.es }}$
}

\begin{abstract}
Among renewable sources, solar energy stands out for its availability and because it can be consumed in the same place where it is produced, reducing its environmental impact.

In order to employ it properly, the energy proceeding from the sun must be characterized with the highest accuracy and reliability. State of the art technologies - including meteorological satellites, advanced software and high precision pyranometers - allows estimating the solar resource with high precision and accuracy, taking into account not only the climatic features of a region, but also its topography.
\end{abstract}

This work collects, for the first time, a highly detailed analysis of the solar radiation in Galicia (NW Spain), using 23 years long series of satellite data together with in situ measurements distributed all across the region. Results show the best accuracy ever recorded.

\section{Key words}

Solar Atlas, satellite measurements, ground based measurements, solar climatology, Spain

\section{Introduction}

Sun provides the Earth almost the entire fraction of the energy to feed the physical and biological processes that take place on the planet. Moreover, solar energy represents the main source of renewable energy in the globe and is clean, inexhaustible and may be consumed in the same place where it is produced. The exploitation of the solar energy highly depends on technology, geographical features and climate. For that, it is necessary to know the amount of insolation and its distribution with the highest precision possible.
Usually, insolation is estimated from ground-based sensors located in particular places of a region. By means of interpolation/extrapolation techniques, maps may be derived from point measurements over the entire location. Moreover, meteorological satellites allow deriving surface irradiance over wider zones.

In literature, several works dealing with the estimation of the solar resource may be found. Those studies point out the need to use both satellite and ground measurements to achieve the best estimation of the solar radiation ([1], [2], [3]).

In Galicia, a previous work was carried out, deriving surface insolation from Meteosat MSG-1 images for the period 2002-2004 [4]. To achieve that, satellite data were calibrated against one pyranometer and validated against another one located in two different points of Galicia, extending the results for a $30000 \mathrm{~km}^{2}$ area.

Taking as reference these works, this study pretends to apply their methodology in the Galician region. In particular, satellite data over a time span of 23 years were analysed as well as the measurements from 28 pyranometers located all over the region.

\section{Analysis tools}

In order to carry out this study, two different data sets were considered:

\section{A. Insolation data derived from satellite}

Starting from 1980, several works focused on estimating solar radiation from satellite observations were carried out. Among them, Heliosat-2 method stands out. This method uses visible band images proceeding from 
geostationary satellites. It has been demonstrated that this method estimates solar radiation accurately enough to generate climatological maps with $10 \mathrm{~km}$ resolution. Insolation data from Meteosat satellites are provided,since 1985, by the Helioclim project (www.helioclim.org).

\section{B. Surface measurements}

Ground based measurements are provided by pyranometers located in several weather stations. In this work were selected mainly station belonging to the local government (Xunta de Galicia) network, managed by MeteoGalicia, the galician weather service. Currently, this network counts on 75 pyranometers located all over Galicia. Those data cover the period (2001-2009). Global radiation data from weather stations belonging to the national weather service (AEMET, www.aemet.es) were also analysed.

\section{Methodology}

\section{A. Insolation data derived from satellite}

Daily irradiance estimations were collected from the SoDa service (Solar Radiation Data; www.Soda-is.com) [2], a part of the HelioClim project. Values between $\left(41.5^{\circ} \mathrm{N}-\right.$ $\left.9.75^{\circ} \mathrm{W}\right)$ and $\left(44^{\circ} \mathrm{N}-6.5^{\circ} \mathrm{W}\right)$ were selected, with $0.05^{\circ}$ resolution ( $5 \mathrm{~km}$ approximately). A grid made up by 3366 nodes was obtained, each one containing data spanning from 1985 to 2008. By means of splines interpolation techniques, data were resampled at a $270 \mathrm{~m}$ resolution.

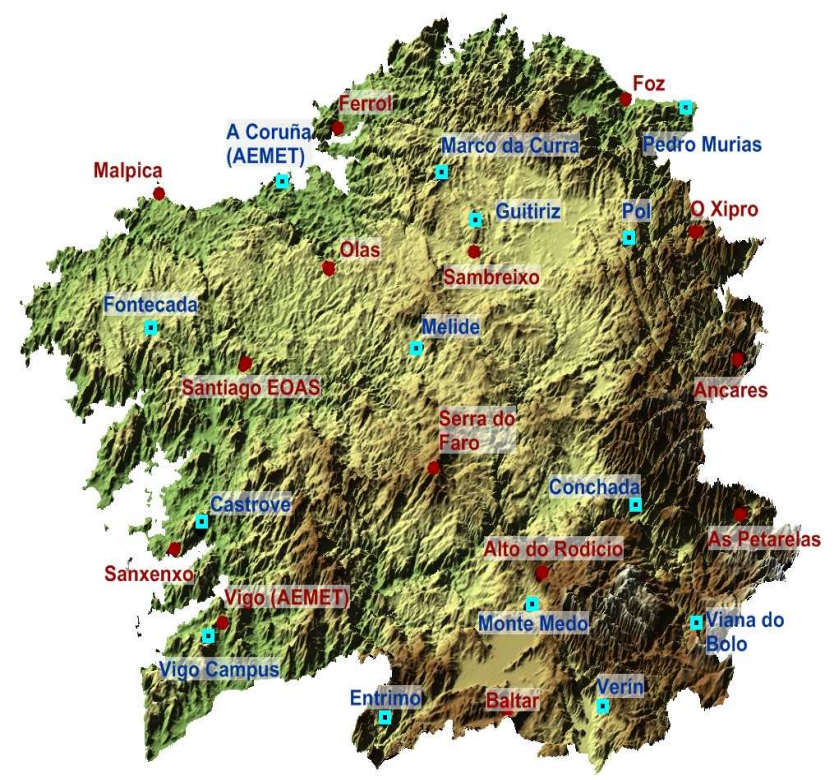

Fig. 1: Location of the calibration (red) and validation (blue) sets

\section{B. Insolation data from pyranometers}

Data proceeding from weather stations were validated, in order to eliminate those values unusually too high (greater than $110 \%$ of clear sky irradiance) or too low (less than $3 \%$ of extraterrestrial radiation). To accomplish this task, a clear sky model was used. Moreover, a visual analysis to detect systematic errors in the pyranometers and comparisons between nearby stations, were also performed. Finally, monthly averages were calculated. As a result of this validation process, 28 locations were selected. Among them, 14 constitute the calibration set and 14 the validation set, as depicted in Figure 1.

\section{Calibration of satellite data with ground based measurements}

By means of residual techniques, the calibration of satellite data was carried out side by side with ground based measurements. First, differences between monthly values of insolation estimated by the Heliosat-2 algorythm and pyranometers data were calculated. Then, those differences were interpolated for Galicia, using Kriging geostatistical technique. Finally, Climatic maps were obtained adding the residual calculated to the original data satellite.

\section{Results and discussion}

The resulting maps were submitted to a validation process, against the validation set previously mentioned, using statistical analysis. To carry out this task, the behaviour of Mean Biased Error (MBE), Mean Absolute Error (MAE) and Root Mean Squared Error (RMSE) were evaluated. Both spatial and temporal analyses were performed. Results obtained were also compared with previous works.

Table I. - MBE [\%] obtained for the different data sets

\begin{tabular}{|c|c|c|}
\hline Month & Satellite & Calibrated Satellite \\
\hline January & 1.57 & 3.29 \\
\hline February & -15.14 & -1.7 \\
\hline March & 0.74 & -3.84 \\
\hline April & 4.34 & 0.37 \\
\hline May & 7.61 & 0.9 \\
\hline June & 3.16 & -1.14 \\
\hline July & 0.43 & -2.04 \\
\hline August & -1.21 & -1.87 \\
\hline September & -10.71 & -3.24 \\
\hline October & -8.82 & -5.25 \\
\hline November & 5.02 & -1.84 \\
\hline December & 11.85 & -1.31 \\
\hline Annual Average & $\mathbf{- 0 . 0 1}$ & $\mathbf{- 1 . 4 7}$ \\
\hline
\end{tabular}

First of all, Tables I-VI point out that the best accuracy is reached by calibrating the satellite with the pyranometers data.

The temporal analysis shows a slight underestimation of the surface insolation. Only taking into account the satellite data, a greater oscillation of the bias is observed, even though it compensates in the annual average (Table I). Analysing the MAE and the RMSE, less oscillation of the bias is produced by the calibrated data (Table II and III). 
The spatial analysis points out that in 8 locations the insolation underestimates the ground based measurements. Thus, the calibrated data provide once more the best agreement, excepting the AEMET stations. In this case, the worse estimations made by the calibrated data set may be due to the presence of local phenomena (haze, fog,...), not detected by the satellite. Nevertheless, as those data do not belong to the regional weather service network, the quality of the measurements could not be guaranteed.

Table II. - MAE [\%] obtained for the different data sets

\begin{tabular}{|c|c|c|}
\hline Month & Satellite & Calibrated Satellite \\
\hline January & 9.5 & 8.65 \\
\hline February & 15.14 & 6.83 \\
\hline March & 6.57 & 6.53 \\
\hline April & 5.84 & 5.4 \\
\hline May & 8.12 & 4.09 \\
\hline June & 7.23 & 5.66 \\
\hline July & 6.67 & 6.1 \\
\hline August & 6.79 & 4.45 \\
\hline September & 11.75 & 5.25 \\
\hline October & 10.67 & 8.03 \\
\hline November & 7.03 & 5.28 \\
\hline December & 12.06 & 4.52 \\
\hline Annual Average & $\mathbf{8 . 9 5}$ & $\mathbf{5 . 9}$ \\
\hline
\end{tabular}

As it can be expected, for the northern hemisphere, maximum values occur in July (Fig. 2), and minimum values in December (Fig. 3). The latitude effect is mitigated by other factors, such as topography and climate, as it can be noticed in the annual average (Fig. 4).

Table III. - RMSE [\%] obtained for the different data sets

\begin{tabular}{|c|c|c|}
\hline Month & Satellite & Calibrated Satellite \\
\hline January & 12.78 & 11.64 \\
\hline February & 16.25 & 9.47 \\
\hline March & 7.97 & 8.44 \\
\hline April & 7.21 & 6.62 \\
\hline May & 9.75 & 5.25 \\
\hline June & 10.01 & 6.72 \\
\hline July & 9.02 & 7.26 \\
\hline August & 9.2 & 5.99 \\
\hline September & 13.65 & 6.73 \\
\hline October & 12.97 & 9.76 \\
\hline November & 9.31 & 7.12 \\
\hline December & 13.77 & 5.49 \\
\hline Annual Average & $\mathbf{1 0 . 9 9}$ & $\mathbf{7 . 5 4}$ \\
\hline
\end{tabular}

Table IV. - MBE [\%] obtained for the different data sets

\begin{tabular}{|c|c|c|}
\hline Station & Satellite & Calibrated Satellite \\
\hline Pedro Murias & 11.4 & 8.85 \\
\hline Coruña (AEMET) & -2.69 & -5.93 \\
\hline Marco da Curra & -4.24 & -2.65 \\
\hline Guitiriz & -4.6 & 0.38 \\
\hline Pol & -7.43 & -1.45 \\
\hline Fontecada & 5 & 4.7 \\
\hline Melide & -6.57 & -4.92 \\
\hline Conchada & -2.17 & -3.5 \\
\hline
\end{tabular}

\begin{tabular}{|c|c|c|}
\hline Castrove & 0.01 & 2.1 \\
\hline Monte Medo & 5.36 & -1.89 \\
\hline Vigo Campus & -3.79 & -9.11 \\
\hline Viana do Bolo & 3.03 & 0.18 \\
\hline Verín & -2.92 & -8.43 \\
\hline Entrimo & 8.28 & 0.84 \\
\hline
\end{tabular}

Table V. - MAE [\%] obtained for the different data sets

\begin{tabular}{|c|c|c|}
\hline Station & Satellite & Calibrated Satellite \\
\hline Pedro Murias & 14.84 & 8.85 \\
\hline Coruña (AEMET) & 4.4 & 6.85 \\
\hline Marco da Curra & 6.53 & 2.65 \\
\hline Guitiriz & 9.27 & 3.72 \\
\hline Pol & 11.63 & 4.36 \\
\hline Fontecada & 7.8 & 4.78 \\
\hline Melide & 10.68 & 6.33 \\
\hline Conchada & 5.9 & 3.71 \\
\hline Castrove & 8.84 & 4.89 \\
\hline Monte Medo & 7.54 & 5.44 \\
\hline Vigo Campus & 6.35 & 9.73 \\
\hline Viana do Bolo & 7.73 & 3.19 \\
\hline Verín & 11.95 & 10.94 \\
\hline Entrimo & 11.8 & 6.91 \\
\hline
\end{tabular}

The results achieved were compared with other studies; in particular with the previous solar atlas of Galicia [4]. Tables VII and VIII resume the comparisons. The analysis of the monthly averages points out that better accuracy is achieved in the present work at both spatial and temporal scales.

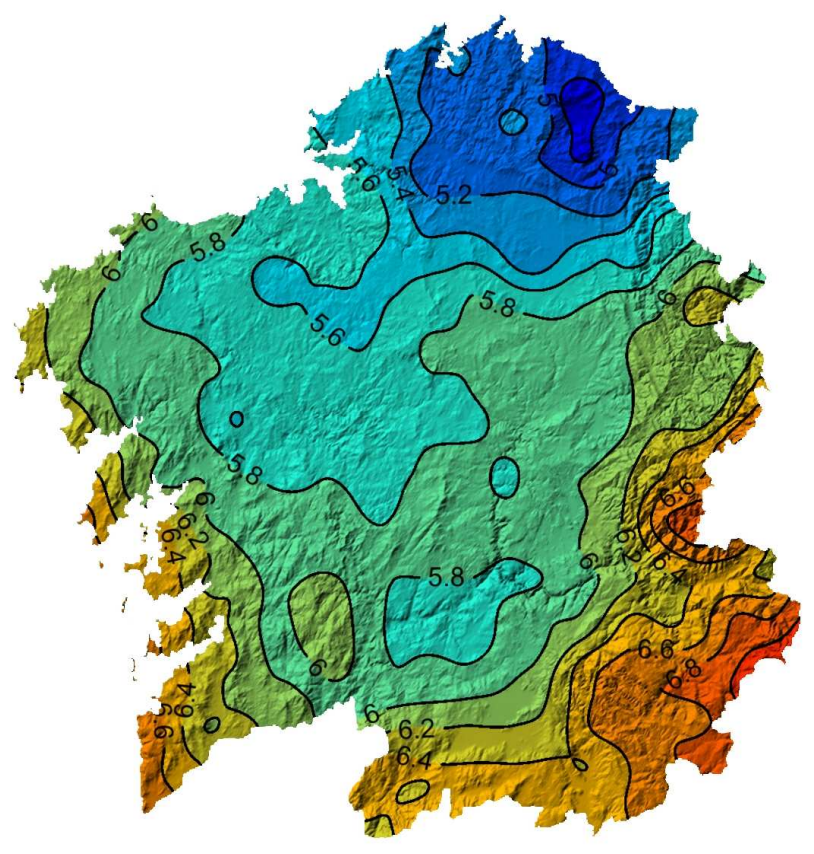

$\begin{array}{llllllllllllllll}4.6 & 4.8 & 5 & 5.2 & 5.4 & 5.6 & 5.8 & 6 & 6.2 & 6.4 & 6.6 & 6.8 & 7 & 7.2\end{array}$

Fig. 2: Monthly averaged Global Insolation [kWh m-2 d-1] July 
Table VI. - RMSE [\%] obtained for the different data sets

\begin{tabular}{|c|c|c|}
\hline Station & Satellite & Calibrated Satellite \\
\hline Pedro Murias & 16.59 & 10.58 \\
\hline Coruña (AEMET) & 7.05 & 8.1 \\
\hline Marco da Curra & 8.87 & 3.48 \\
\hline Guitiriz & 11.3 & 4.45 \\
\hline Pol & 14.42 & 5.49 \\
\hline Fontecada & 8.98 & 6.11 \\
\hline Melide & 13.42 & 8 \\
\hline Conchada & 8.07 & 4.36 \\
\hline Castrove & 10.29 & 6.7 \\
\hline Monte Medo & 10.08 & 6.18 \\
\hline Vigo Campus & 7.63 & 11.12 \\
\hline Viana do Bolo & 8.26 & 4 \\
\hline Verín & 13.19 & 12.39 \\
\hline Entrimo & 14.78 & 10.36 \\
\hline
\end{tabular}

Table VII. - Temporal validation of the previous solar atlas of Galicia

\begin{tabular}{|c|c|c|}
\hline Month & MAE [\%] & RMSE [\%] \\
\hline January & 9.2 & 11.62 \\
\hline February & 16.06 & 17.61 \\
\hline March & 8.15 & 9.37 \\
\hline April & 7 & 8.5 \\
\hline May & 11.11 & 11.98 \\
\hline June & 9.95 & 11.76 \\
\hline July & 5.02 & 6.92 \\
\hline August & 6.72 & 8.37 \\
\hline September & 8.59 & 10.24 \\
\hline October & 15.96 & 17.66 \\
\hline November & 8.25 & 10.05 \\
\hline December & 6.21 & 7.4 \\
\hline Annual Average & $\mathbf{9 . 3 5}$ & $\mathbf{1 0 . 9 6}$ \\
\hline
\end{tabular}

Table VIII. - Spatial validation of the previous solar atlas of Galicia

\begin{tabular}{|c|c|c|}
\hline Station & MAE [\%] & RMSE [\%] \\
\hline Pedro Murias & 15.32 & 16.31 \\
\hline Coruña (AEMET) & 4.09 & 5.04 \\
\hline Marco da Curra & 4.97 & 7.05 \\
\hline Guitiriz & 9.16 & 10.2 \\
\hline Pol & 10.48 & 12.77 \\
\hline Fontecada & 6.01 & 8.38 \\
\hline Melide & 10.18 & 12.89 \\
\hline Conchada & 7.11 & 8.54 \\
\hline Castrove & 11.17 & 13.07 \\
\hline Monte Medo & 7.71 & 9.3 \\
\hline Vigo Campus & 10.52 & 12.06 \\
\hline Viana do Bolo & 8.49 & 9.88 \\
\hline Verín & 14.8 & 16.42 \\
\hline Entrimo & 10.89 & 12.38 \\
\hline
\end{tabular}

\section{Conclusions}

In order to exploit successfully the solar resource available in a given region, it is mandatory to know with the highest precision the amount and distribution (temporal and spatial) of the incoming solar radiation.
This study pretended to improve the quality and the knowledge of the solar resource in Galicia. To achieve this goal, 23 years long series of satellite data and ground based pyranometers were merged together.

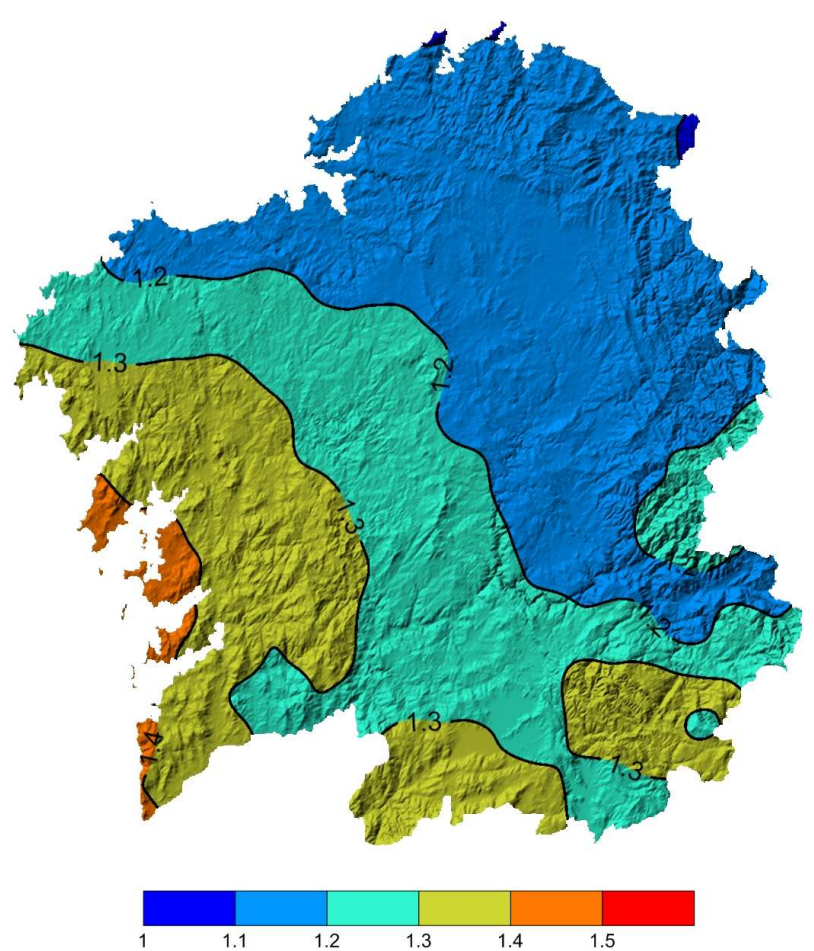

Fig. 3: Monthly averaged Global Insolation [kWh m-2 d-1] December

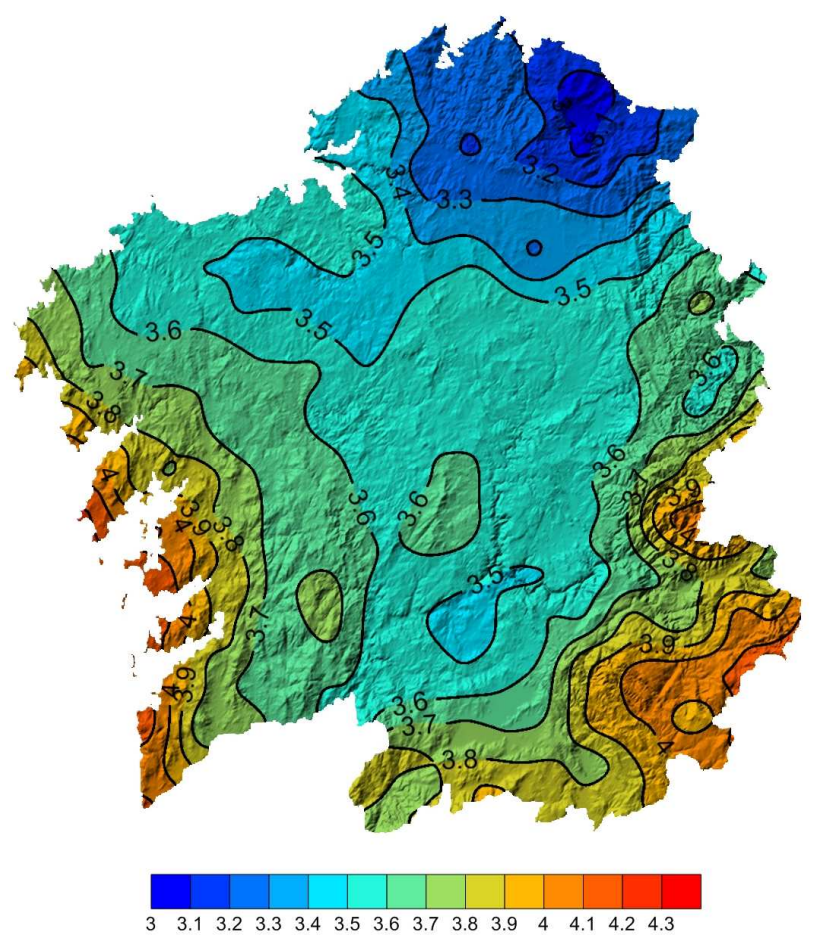

Fig. 4: Annual averaged Global Insolation [kWh m-2 d-1]

The results point out a remarkable improvement of the quality of the estimated insolation. When properly calibrated with ground measurements, satellite data represent an extremely powerful tool to assess the solar resource over a region. Actually, annual averages of MAE and RMSE are 5.9\% and 7.5\% respectively, against 
almost $9 \%$ and $11 \%$ obtained taking into account satellite data only. At monthly scale, the improvement may be even better. Compared to previous studies, this work shows better accuracy in estimating the global insolation in Galicia, probably due to the calibration process, including more pyranometers in the data set.

\section{References}

[1] Vera Mella N. (2005). Atlas climatico de irradiacion solar a partir de imàgenes del satélite NOOA. Aplicaciòn a la Peninsula Ibérica. Tesis Doctoral. Universidad Politécnica de Cataluna.

[2] Hiser H. W., Senn H. V. (1980). Mesoscale mapping of available solar energy at Earth's surface by use of satellites. Solar Energy, 24, 2, 129-141

[3] Cano D., Monget M., Albuisson M., Guillard H., Regas N., Wald L. (1986). A method for the determination of the global radiation from meteorological satellites data. Solar Energy, 37, 1, 31-39

[4] VàzquezM., Santos J. M., Prado M., Rodrigues F. M., (2005). Atlas de radiaciòn solar de Galicia. Universidad de Vigo. 